\title{
Implementation Model of Non-Cash Food Aid in Social Protection in Ngawi District
}

\author{
Agus Wiyaka and Endang Murti \\ Faculty of Social and Political Sciences, University of Merdeka Madiun
}

\begin{abstract}
In realizing a prosperous, just and prosperous society in accordance with the ideals of the Indonesian people, it is necessary to ensure a sustainable program in improving the welfare of the community. One of the poverty reduction programs in Indonesia is the Non-Cash Food Assistance Program. Non-Cash Food Assistance is food social assistance in the form of non-cash from the government that is given to Beneficiary Families every month through an electronic account mechanism that is used only to purchase foodstuffs at foodstuff traders / e-warong in collaboration with bank. Meanwhile, the purpose of this study was to determine the Implementation Model of Non-cash Food Assistance for Social Protection in Geneng and Gerih Districts, Ngawi Regency. In this study using the Participatory Action Research method. The research object is Beneficiary Families of Non-Tunia Food Assistance, while the research subjects are Government and society in Ngawi Regency, East Java, which is represented by government officials and communities in the Geneng and Gerih districts of Ngawi Regency. Data collection techniques used in this study were interviews (interviews), observation (observation), and documents (documentation). The data analysis method uses an interactive model. The research findings show that (1) Communication between organizations, namely Gerih and Geneng Districts with the Social Service of Ngawi Regency in the selection of Electronic Mutual Cooperation (E-Warong) Warung has been able to run well and optimally; (2) Resources in this case in the form of facilities and infrastructure to implement non-cash food assistance are very adequate. at E-Warong. (3) The attitude of the implementers has been optimal, but there is still a need for more intensive socialization and guidance to people who still do not understand. (4) In its implementation in the field, Non-Cash Food Assistance is equipped with Standard Operating Procedures (SOP) as a guideline for officers in the field. The organizational structure that handles and is directly responsible for the success of non-cash food assistance is relatively effective and flexible, thus facilitating supervision in its implementation.
\end{abstract}

Keywords: Food, social protection, poverty alleviation

DOI: $10.7176 /$ RHSS/10-18-03

Publication date:September $30^{\text {th }} 2020$

\section{I.PRELIMINARY}

Food is a basic human need that must be fulfilled because it is a source of energy to sustain life. The right to obtain food is one of the human rights, as stated in article 27 of the 1945 Constitution. Therefore, as a basic need and one of the human rights, food has an important meaning for the life of a nation. Food in Indonesia has an important position, especially staple food, because it involves political, economic, social and cultural issues (Prabowo, 2010). In line with that, the history of the food economy of the Unitary State of the Republic of Indonesia (NKRI) clearly notes that the leaders of this country have consistently put the food economy as something very strategic (Suryana 2008). Poverty and Food Vulnerability in Indonesia is a challenge that the government faces from time to time. Poverty is a complex problem that requires integrated and sustainable management and programs (Bappenas, 2017). In an effort to alleviate poverty and increase people's access to food, the government uses various programs and stimuli. One of them was the Prosperous Rice Program (Rastra) which was transformed into Non-Cash Food Assistance. In the long term, the distribution of food aid on a non-cash basis is expected to have an impact on improving the welfare and economic capacity of the beneficiaries. Distribution of the Non-Cash Food Assistance Program (BPNT) began in 2017 in 44 cities that have adequate access and facilities. Gradually, food aid was expanded to all cities and districts in accordance with the readiness of the facilities and infrastructure for non-cash distribution. Starting in 2018, the Rastra subsidy has also been converted into social assistance called Bansos Rastra. Thus, Food Social Assistance is distributed to each district / city in the form of non-cash or in-kind, that is, still in the form of rice. Some districts whose non-cash distribution facilities are inadequate, still distribute Rastra but without the ransom price to be paid by Beneficiary Families (KPM). In 2019, the BPNT Program continued to be expanded to districts / cities which in 2018 were still implementing the Bansos Rastra Program. For expansion in 2019, the implementation of BPNT will be carried out using two mechanisms. First, using a mechanism that has been in place since 2017. Second, using a special mechanism for district areas in accordance with the assessment of the Control Team and decided by the Director General for the Management of the Poor, Ministry of Social Affairs. In order for the implementation of the BPNT Program to run well and achieve its objectives, it is necessary to have General Guidelines for Non-Cash Food Assistance which are formulated as guidance, direction or implementation reference in the field. These General Guidelines are intended to be used by program 
implementers, namely: Central Government, Regional Government, BPNT Distribution Banks, e-Warong as agents for distributing foodstuffs and other related parties. The Guidelines will be complemented by Technical Instructions for the more detail ed mechanisms.Several research results indicate that BPNT guarantees the availability of a portion of the rice needed by KPM. Rachman et al. (2018) stated that the contribution of BPNT in meeting rice needs in five cities. Household income has a very large effect on the level of consumption. Usually the higher the income, the higher the level of consumption. As income levels increase, the ability of households to buy various consumption needs becomes large or perhaps their lifestyle becomes increasingly consumptive (Rahardja and Manurung 2008). BPNT provides additional income to KPM, which is suspected of influencing KPM's behavior in determining the type of food it will consume, thereby changing its consumption patterns. Any change in income will provide a response different in each household and different in each food group to be consumed. Poor households have low income, consequently their purchasing power is also low. Therefore, poor households are very concerned about the price of the food they consume. Price is a factor that influences household demand. Apart from considering the price of food to be consumed, households also consider other food prices which are interrelated (Rahardja and Manurung 2008). The number of households also affects the amount of household food consumption. As the number of family members increases, the demand for food will generally increase. Another factor that is thought to influence the pattern of food demand for poor households is BPNT membership. It is suspected that there are differences in the pattern of food demand between BPNT households and non-BPNT households. This is because BPNT KPM no longer spends money to get food assistance in the form of rice and / or eggs while non-BPNT households spend money to get rice and / or eggs. Problems that have arisen in several regions include that there are still people who receive BPNT cards who have not entered their balance on their cards so the problem lies with the social assistance distribution bank. Therefore, banks must improve data on aid recipients, so that people are not worried about the problem of cards that have not been filled in balance, the Bank as one of the aid providers must immediately improve existing data, so that people can benefit from social assistance cards from the government. the. In addition to the above, there is still a problem of changing BPNT recipient data for people who are no longer an indicator of aid recipients because they have been successful and economically successful, in fact they still get social assistance from the government, this is a problem in itself. Because the data change is constrained by the length of time updating data from the center, which is only once every six months. This is a problem in the community, because they are still receiving assistance, when they have crossed out from PBNT recipients and want to give them to other people or those who are in line under them experience a long problem in changing their data. Based on the description above, the problem in this research can be formulated as follows: How is the model for implementing non-cash food assistance for social protection in Geneng and Gerih sub-districts, Ngawi regency. The purpose of this study was to determine the implementation model of Non-Cash Food Assistance for Social Protection in Geneng and Gerih Districts, Ngawi Regency.

\section{RESEARCH METHODS}

\section{Research Achievements and Stages}

This research uses the Participatory Action Research (PAR) method, according to Agus Afandi (2014) research that actively involves all relevant parties (stakeholders) in assessing ongoing actions (where their own experiences are a problem) in order to make changes and improvement for the better. While the activities carried out in terms of the achievements and stages of the research include:

1. Identifying problems or looking for problems: This stage, the researcher must first look for what problems to be researched.

2. Formulating a problem: Where at this stage it is a continuation of problem discovery which then the researcher makes a problem formulation based on the problems to be studied. Make it operational and define the problem, especially in determining the scope of the problem under study.

3. Conduct a preliminary study: This is done with the aim of gathering information related to the problem to be studied. So that it can be known the situation or position of the problem both theoretically and practically. The knowledge gained from preliminary studies is very useful for compiling a theoretical framework of problem solving in the form of hypotheses that will be verified through the implementation of field research. Preliminary studies can be carried out by documentary studies, literature and field studies.

4. Determining the research sample: At this stage, the object to be studied is determined. The entire object to be studied is called the research population. If the research uses only part of the population, then in this case it is sufficient to use a sample.

5. Develop a research plan: This stage is a guide for carrying out research. As a planning pattern, it must be able to reveal matters related to research implementation activities.

\section{Location and Object of Research}

As for the definition of the object of research according to Sugiyono (2012: 13), "The object of research is a scientific objective to obtain data with specific purposes and uses about something objective, valid, and reliable 
about something (certain variables)". The location and object of research in the Ngawi Regency area as an area that represents / reflects the people of West East Java in terms of community aspects with traditional and industrial cultures, agriculture and plantations.

\section{Research Samples and Respondents}

This opinion of Gay and Diehl (1992) assumes that the more samples that are taken, the more representative and the results can be digenized. However, the accepted sample size will depend largely on the type of research. Sampling using multi stage sampling technique. The research object is Beneficiary Families (KPM) of Non-Tunia Food Assistance, while the research subjects are Government and society in Ngawi Regency, East Java, represented by government officials and communities in the Geneng and Gerih districts of Ngawi Regency. Furthermore, some were taken to be used as samples / research respondents by "purposive sampling". The definition of purposive sampling technique according to Arikunto (2006) is a technique of taking samples not based on random, regional or strata, but based on considerations that focus on certain objectives.

\section{Data collection technique}

Data collection techniques are a way of collecting data needed to answer the formulation of research problems. Juliansyah Noor (2011: 138). Data collection techniques used in this study are interviews (interviews), observation (observation), and documents (documentation). Meanwhile, to test the validity of the data is to use triangulation of data sources.

\section{Research Analysis Methods}

The data analysis method uses an interactive model. According to Matthew B. Miles and Michael Huberman in Moleong (2007), it is explained that in carrying out the analysis process the main components that need to be considered after data collection are:

1. Data reduction, namely the process of selecting, simplifying, abstracting and transforming raw data from written notes in the field to a complete final report.

2. Presentation of data, namely a set of information arranged in order to provide the possibility to draw conclusions. In presenting this data is done after reducing the data that will be used as report material.

3. Draw conclusions or verification, which is in the form of the essence of data presentation which is the result of the analysis carried out in the research

\section{RESULTS AND DISCUSSION}

The Non-Cash Food Assistance Program in 2019, in its implementation, is carried out using two mechanisms. First, using a mechanism that has been in place since 2017. Second, using a special mechanism for district areas in accordance with the assessment of the Control Team and decided by the Director General for the Management of the Poor, Ministry of Social Affairs.

Ngawi Regency, East Java Province is one of the Regencies and Cities in East Java that has benefited from Non-Cash Food Assistance. The implementation of the BPNT program throughout 2018, most of the Beneficiary Families (KPM) expressed their satisfaction with the implementation process, while Ewarong managers also expressed satisfaction with the implementation of the program. The research indicators show that KPM and Ewarong both feel that the 2018 BPNT Program activities carried out in Ngawi Regency are very easy to understand and comfortable, so that both KPM and E-warong have benefited positively from the implementation of the BPNT which was carried out for the first time. as a substitute for the Prosperous Rice Family program. In accordance with the title in the study, namely the Non-Cash Food Assistance Program Implementation Model (BPNT), the authors formulated the Non-Cash Assistance Program Implementation Model in Gerih District and Geneng District, Ngawi Regency. The Implementation Model of the Non-Cash Food Assistance Program in Gerih and Geneng Subdistricts, Ngawi Regency in 2019 which was analyzed using the public policy theory approach according to George C. Edward III. There are 4 (four) variables that influence policy implementation, namely communication, resources, disposition, and bureaucratic structure. The four variables are interrelated with one another. The Implementation Model of the Non-Cash Food Assistance Program in Gerih District and Geneng District, Ngawi Regency in 2019 can be seen in Figure 1 below. 


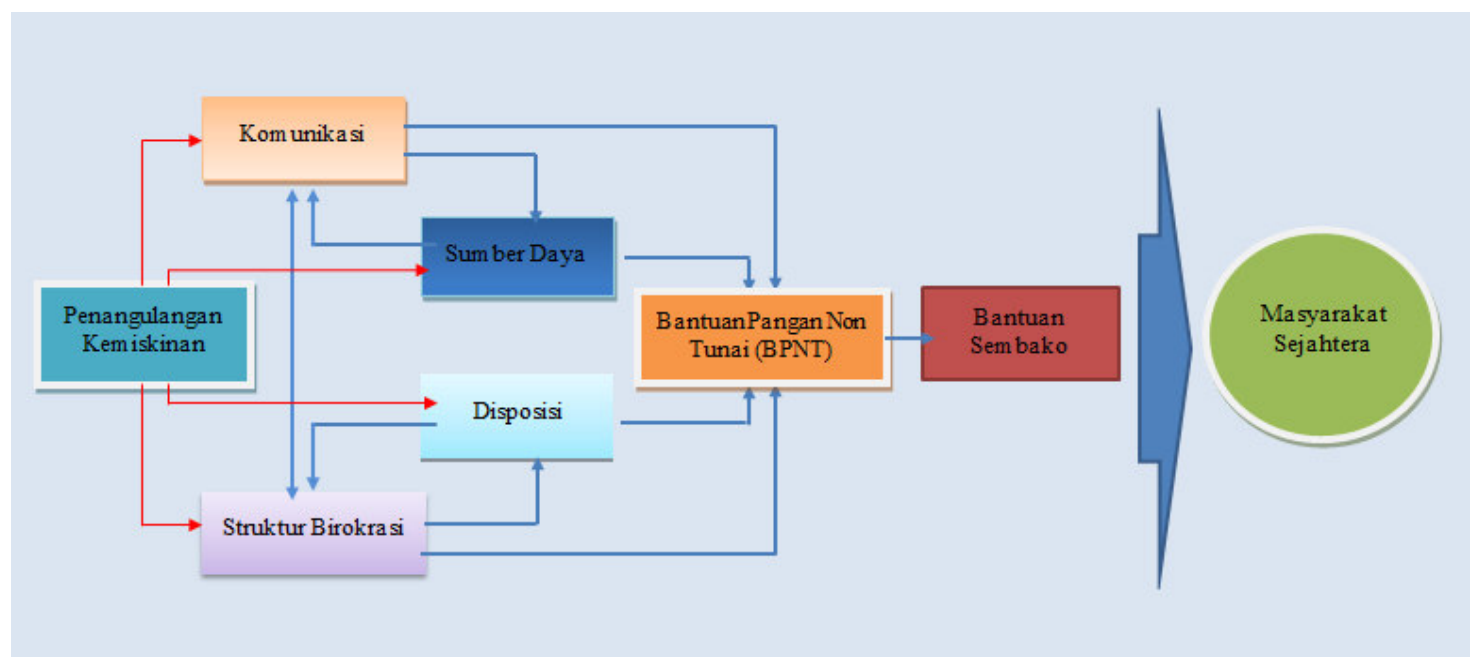

Figure 1.

Policy Implementation Model of the Non-Cash Food Assistance Program (BPNT)in Gerih District and Geneng District, Ngawi Regency.

The Model of Non-Cash Food Assistance Program (BPNT) Policy Implementation in Gerih and Geneng Districts, Ngawi District can be explained below.

1. Communication

Communication is the process of delivering information from the communicator to the communicant. Meanwhile, policy communication means the process of delivering policy information from policy makers to policy implementers. Information needs to be conveyed to policy actors so that policy actors can understand what is the content, purpose, direction, target group of the policy, so that policy actors can prepare any matters related to policy implementation, so that the policy implementation process can run effectively and in accordance with the objectives of the policy itself (Widodo, 2011: 97).

Communication in policy implementation includes several important dimensions, namely information transformation (transmission), clarity of information (clarity) and consistency of information (consistency). The transformation dimension requires that information is not only conveyed to policy implementers but also to target groups and related parties. The clarity dimension requires information that is clear and easy to understand, in addition to avoiding misinterpretation of policy implementers, target groups and parties involved in policy implementation. Meanwhile, the consistency dimension requires that the information conveyed be consistent so as not to cause confusion among policy implementers, target groups or related parties. The importance of cooperation and communication between organizations is to achieve goals with satisfactory results and in accordance with what is expected from a policy. Cooperation and communication cannot run independently but these two things can make a policy work effectively when there is a collaboration that can run simultaneously. Policies sometimes cannot be implemented effectively not because they have been implemented poorly, but because they are policies itself is not yet focused. The cause of all this is none other than the fact that wisdom is based on an inadequate level of understanding of the issues to be addressed, the causes of problems and the ways of solving them. Policies related to cause and effect depend on a very long chain, so it will easily experience cracks, because the longer the chain, the greater the reciprocal relationship between the linking links and the more complex its implementation (Nugroho, 2004: 34).

Based on the results of the study and the results of interviews with various parties related to Non-Cash Food Assistance, it can be seen that communication between organizations, namely Gerih and Geneng Districts with the Social Service of Ngawi Regency in the selection of Electronic Mutual Cooperation (EWarong) Warung has been running well and optimally. The community has known the existence of E-Warong as a place to take advantage of non-cash food assistance. The community also knows about the media or tools to get basic food assistance, namely through the Prosperous Family Card (KKS). In the case of taking non-cash food aid, there is no accumulation or long queues.

2. Resources

Resources have an important role in policy implementation. Edward III in Widodo (2011: 98) argues that: no matter how clear and consistent the provisions and rules are and however accurate the delivery of the provisions or rules is, if the policy implementers who are responsible for implementing the policy lack the resources resources to implement policies effectively, the implementation of these policies will not be effective. Resources here relate to all sources that can be used to support the successful implementation of policies. These resources include human resources, budget, facilities, information and authority. Resources in the implementation of noncash food assistance in this study include facilities and infrastructure to support program activities. In general, 
facilities and infrastructure are tools to support the success of a process of efforts made in public services, because if these two things are not available then all activities carried out will not be able to achieve the expected results according to plan. In the case of facilities and infrastructure related to non-cash food assistance through E-Warong, Based on the results of an interview with a staff of the Ngawi District Social Service, he said that: "The facilities and infrastructure for implementing the current Non-Cash Food Assistance policy are very adequate. The number of E-Warong in Gerih Subdistrict and Geneng Subdistrict is more than sufficient to serve the community who are beneficiaries of the Staple Food Program, namely families with the lowest socio-economic conditions in the Gerih sub-district and Geneng district, Ngawi district. The above statement explains that the facilities and infrastructure to carry out this policy are very adequate, the number of EWarong in Gerih and Geneng Districts as facilities and infrastructure to carry out this policy is very sufficient. Furthermore, a similar sentiment was also expressed by the Gerih Subdistrict Social Welfare Officer, he said: "We as implementers feel calm, comfortable and happy, because there is no shortage of facilities and infrastructure. E-Warong in Gerih District is able to serve all recipients of non-cash food aid beneficiaries. The author analyzes the results of the interview above, it is known that regarding the facilities and infrastructure all informants give good responses. This is in accordance with the theory put forward by Van Meter and Van Horn in Subarsono (2013: 100) that the success of the policy implementation process is highly dependent on the ability to utilize available resources. The availability of the required resources supports the success of the policy. What must be emphasized is that the resources are sufficient and used or useful so that budget waste does not occur.

3. Disposition

The behavioral trends or characteristics of policy implementers play an important role in realizing the implementation of policies in accordance with the goals or objectives. Important characteristics that must be possessed by policy implementers are honesty and high commitment. Honesty directs implementers to stay in the program's outlined hope, while the high commitment of the policy implementers will make them always enthusiastic in carrying out their duties, powers, functions, and responsibilities in accordance with predetermined regulations. The attitude of the policy implementer will greatly influence policy implementation. If the implementer has a good attitude, he will be able to carry out the policy well as what the policy maker wants, on the other hand, if the attitude is not supportive, the implementation will not be carried out well. The disposition or attitude of the implementers, namely the tendency of the implementers to point to characteristics that stick closely to the implementers of the policy or program. The attitude of the implementers is needed in carrying out a policy. In the policy implementation process, we must be able to see how much power the policy makers and implementers of policy programs have so that the goals to be achieved will be clearer. It's just that if the greater the influence of interests, it will be a little difficult to implement the policy. In addition, an implementor must be able to plan strategies that will be used to implement policies. The attitude of acceptance or rejection of policy implementing agencies greatly influences the success or failure of public policy implementation. Public policy is usually top down in nature, which makes it possible for decision makers not to know or even to be able to address the needs, wants or problems that must be resolved. So a picture of commitment and honesty is needed to see the consistency between implementing activities and the appointed agent. Based on the results of the interview, it is known that the disposition or attitude of the implementers in implementing the Basic Food Assistance Social Program policy through E-Warong is in accordance with the policy. The ability of the implementers to achieve the success of this policy has been optimal. This attitude is very important for the success of a policy. Furthermore, the researcher conducted an interview with the Geneng Subdistrict Social Welfare Officer, he said: "Non-cash food assistance that is distributed through E-Warong in serving KPM is quite good. We always provide direction to KPM who do not understand the transaction mechanism carried out at E-Warong. We always try to provide assistance to KPM who do not understand, so KPM will not find it difficult to get this assistance and are happy to have been assisted with basic necessities by the government". The results of this study the authors draw the conclusion that in general the officers who implement the Non-Cash Food Assistance policy through E-Warong have been well felt by beneficiary communities and owners of E-Warong. However, the community still needs assistance from officers when making transactions at E-Warong. So that the author can categorize the disposition of the implementers' attitudes as optimal, but there is still a need for more intensive socialization and guidance to people who still do not understand.

4. Bureaucratic Structure

The organizational structure has a significant influence on policy implementation. This aspect of the organizational structure covers two things, namely the mechanism and structure of the bureaucracy itself. The first aspect is that the mechanism for implementing policies is usually made up of a standard operation procedure (SOP). SOPs serve as guidelines for every implementer in acting so that policy implementation does not deviate from policy goals and objectives. The second aspect is the bureaucratic structure, a bureaucratic structure that is too long and fragmented will tend to weaken supervision and lead to complicated and complex bureaucratic procedures which in turn will cause organizational activities to be inflexible. In its implementation, Non-Cash Food Assistance is equipped with Standard Operating Procedures (SOPs) as guidelines for officers in the field. Apart from being a 
guideline for the task of distributing non-cash food assistance to KPM, this SOP is always socialized to KPM in order to know the correct food distribution procedures and mechanisms. The organizational structure that handles and is directly responsible for the success of non-cash food assistance is relatively effective and flexible, thus facilitating supervision in its implementation. Based on interviews with officers from the Ngawi District Social Service, he said that "non-cash food assistance in its implementation in the field is equipped with SOPs, this certainly makes it easier for us officers in the field to succeed in the social program for basic food assistance to KPM".

\section{CONCLUSION}

Based on the findings of research on the Implementation Model of Non-Cash Food Assistance in the Context of Social Protection in Geneng and Gerih Subdistricts, Ngawi Regency, it can be concluded that (1) Communication between organizations, namely Gerih and Geneng Districts with the Ngawi Regency Social Service in the selection of Electronic Mutual Cooperation Stalls (E- Warong) has been able to run well and optimally. The community has known the existence of E-Warong as a place to take advantage of non-cash food assistance. The community also knows the media or tools to get non-cash food assistance, namely through the Prosperous Family Card (KKS). (2) Resources in this case in the form of facilities and infrastructure to implement non-cash food assistance are very adequate. at E-Warong. (3) In general, officers implementing the non-cash food assistance policy through EWarong have been well felt by the beneficiaries and owners of E-Warong. However, the community still needs assistance from officers when making transactions at E-Warong. So that the author can categorize the disposition of the attitude of the implementers as optimal, but there is still a need for more intensive socialization and guidance to people who still do not understand. (4) Non-cash Food Assistance in its implementation in the field has been equipped with Standard Operating Procedures (SOP) as a guideline for officers in the field. Apart from being a guideline for officers to implement non-cash food assistance to KPM, SOPs are also always socialized to KPM in order to know the procedures and mechanisms for distributing basic necessities. In addition, the organizational structure that handles and is directly responsible for the success of non-cash food assistance is relatively effective and flexible, thereby facilitating supervision in its implementation. The implementation of BPNT so that in the future it can be more effective in overcoming poverty in the community, the BPNT program should be continued by the government because it has a significant effect on fulfilling the basic needs of the poor, namely the basic necessities of life such as rice, sugar, eggs and so on. The central and regional governments need to pay attention to the synergy between the food aid program, where food aid is not used to buy necessities other than basic food needs such as cigarettes.

\section{DAFTAR PUSTAKA}

Abidin, Said, Zainal, 2004, Kebijakan Publik, Jakarta: Pancur Siwah

Afandi, Agus. 2014. Modul Participatory Action Research (PAR), Untuk Pengorganisasian Masyarakat (Community Organizing. Surabaya :Lembaga Penelitian dan Pengabdian Kepada Masyarakat (LPPM) UIN Sunan Ampel.

Agus Wiyaka, Endang Murti, Implementasi Program Bantuan Pangan Non Tunai (BPNT) Dalam Perlindungan Sosial Di Kecamatan Gerih Dan Kecamatan Geneng Kabupaten Ngawi Tahun 2018. Seminar Nasional Sistem Informasi 2019, 19 September 2019 Fakultas Teknologi Informasi - UNMER Malang.

Agus Wiyaka, Endang Murti, Journal International Developing Country Studies www.iiste.org ISSN 2224-607X (Paper) ISSN 2225-0565 (Online) Vol.7, No.9, 2017 Model of Rastra Program in the Framework of Social Protection of Pre-Prosperous Society in Kendal District, Gerih and Kwadungan of Ngawi Regency

Anderson, J, (1978). Public Policy-Making, Second edition, Holt, Rinehart and Winston: 1979 dalam Islamy, Irfan, Prinsip-Prinsip Perumusan Kebijakan Negara, Cetakan 12, Bumi Aksara, Jakarta:2003.

Arikunto, S. 2006. Prosedur Penelitian Suatu Pendekatan Praktik, Jakarta: Rineka Cipta.

Budi Winarno, 2002. Teori dan Proses Kebijakan Publik, Yogyakarta: Media Presindo.

Dunn, William N. 1999. Analisis Kebijakan Publik, Yogyakarta: Gajah Mada University Press.

Dye, Thomas R. 1992. Understanding Public Policy. New Jersey: Englewood. Cliffs.

Edward, George. C.1980. Implementing Public Policy. Washington D.C: Congressional Quarterly Inc.

Gay, L.R. dan Diehl, P.L. (1992), Research Methods for Business and. Management, MacMillan Publishing Company, New York

J. Moleong, Lexy. 2007. Metode Penelitian Kualitatif. Remaja Rosdakarya; Bandung.

M.Irfan Islami, 2002. Prinsip-Prinsip Perumusan Kebijakan Negara, Jakarta: Sinar Grafika

Materi Sosialisasi Bantuan Pangan Non Tunai (BPNT), Maret 2018, Jakarta

Miles, Matthew B. and A. Michael Huberman. 2005. Qualitative Data Analysis (terjemahan). Jakarta : UI Press.

Noor, Juliansyah, Metodologi Penelitian : Skripsi, Tesis, Disertasi, \& Karya Ilmiah, Jakarta: Kencana Prenada Media Group, 2011.

Nugroho D, Riant. 2004. Kebijakan Publik, Formulasi, Implementasi, dan Evaluasi. Jakarta: Gramedia. 
Pedoman Umum Bantuan Pangan Non Tunai, Cetatakan Pertama, Nopember, 2017.

Peraturan Menteri Koordinator Bidang Pembangunan Manusia dan Kebudayaan Republik Indonesia nomor 1 tahun 2016 tentang Pedoman Umum Subsidi beras bagi masyarakat berpendapatan rendah tahun 2016

Prabowo, Rossi. 2010. "Kebijakan Pemerintah dalam Mewujudkan Ketahanan Pangan di Indonesia”, Jurnal Ilmuilmu Pertanian, Vol. 6 No. 2. Jakarta, 62

Prathama Rahardja, Mandala Manurung. 2008. Teori Ekonomi Makro. Jakarta: LPFEUI

Riant, Nugroho D. (2004). Kebijakan Publik: Formulasi, Implementasi dan Evaluasi.

Scott, Z. (2012).Topic Guide on Social Protection. Birmingham: Governance and Social Development Resource Center.Social Assistance as an Economic Investment for Indonesia, presented in Social Protection Knowledge Collaboration Event 1: Maximising Growth -Making Sure Everyone Benefits

Solichin, Abdul Wahab, 2002. Analisis Kebijaksanan Dari Formulasi ke Implementasi Kebijaksanaan Negara, Jakarta: Sinar Grafika.

Subarsono, AG, 2010. Analisis Kebijakan Public, Yogyakarta : Pustak Pelajar.

Sugiyono, 2012. Metode Penelitian Sosial. Bandung: Alfabeta.

Suharto, Edi (2005b), Analisis Kebijakan Publik: Panduan Praktis Mengkaji Masalah dan Kebijakan Sosial, Bandung: Alfabeta.

Suryana. 2008. Kewirausahaan Pedoman Praktis: Kiat Dan Proses Menuju Sukses, Edisi Tiga. Jakarta: Salemba Empat.

Undang - Undang Nomor 11 Tahun 2009 tentang Kesejahteraan Sosial.

Van Meter, D. S., \& Van Horn, C. E. (1973). The policy implementation process a conceptual framework in administration and society. Beverly Hills: Sage Publication.

Widodo. 2011. Analisis Kebijakan Publik: Konsep dan Aplikasi Analisis Proses Kebijakan Publik. Malang: Bayu Media. 